\title{
The Norman Fiefs in Palestine
}

\section{R. Conder}

To cite this article: C. R. Conder (1889) The Norman Fiefs in Palestine, Palestine Exploration Quarterly, 21:4, 201-202, DOI: 10.1179/peq.1889.21.4.201

To link to this article: http://dx.doi.org/10.1179/peq.1889.21.4.201

曲 Published online: 20 Nov 2013.

Submit your article to this journal $\widetilde{ }$

Џ Article views: 3

Q View related articles $\sqsubset$ 
shed, the regions further east and south are unnoticed, and the property described is that of public bodies not of the original fief-holding knights. The army alone is calculated to have consisted of some 20,000 to 25,000 men in all (see "Syrian Stone Lore," p. 428), and the population was probably at least equal to that of our own times.

It should be noticed that crusading ruins are mentioned in the "Memoirs" at a great many of the sites, which are included in the above-named lists.

C. R. C.

\section{THE NORMAN FIEFS IN PALESTINE.}

By identification of the various towins in Palestine mentioned in Norman documents, it becomes possible to define the limits of the fiefs, and these I have now laid down on the Survey Map. The fief of Sagette (Sidon), including the Land of Schouf-now Jebel Shaf-lay beyond the limits of the Survey on the north, being bounded on the south by the Kasiminyeh gorge, but including the Merj 'Ayân and the important castle of Belfort. South of this line the following were the divisions :-

(1.) The Seigneurie of Tyre, from the Kasimîyeh on the north to the Ladder of Tyre on the south, including the lower hills on the east to Zubkîn, Reshkananîn, Baflei, and Nìha:

(2.) The Seigneurie of Toron, held by the Courtney family, east of the last, and extending in a southern direction to Harfeish.

(3.) The Seigneurie of Renier of Marun, including Marin er Râs on the south-west, and the towns Mees (Meis), Belide (Belîdeh), Cades (Kades), and Chateau Neuf (Hunîn). It appears to have reached to the Jordan Valley.

(4.) The Seigneurie of Montfort, between (1) and (2), extended from Aithire (Y'ater) on the north to Jeth (Jett) on the south. On the west it included Judyn (Kul'at Jiddîn), Zoenite (Zueinîta), and Tabaria (Tibria) reaching to the plains of Acre.

(5.) The Seigneurne of St. George of Labeyne, from Beit Jenn on the east to Gelon (Jallan) on the west, and from Bucael (el Bukei'ah) on the north to Wâdy Halzân on the south. St. George of Labeyne was the present $E l B^{\prime}$ aneh, near which is the shrine of $E l K h u d r$ (St. George).

(6.) The Territory of Acre, from the Ladder of Tyre to the Kishon, and extending from the sea to the mountains west of Caphar Mada and Zekanin (Kefr Menda and Sukhnìn).

(7.) The Seigneurie of Cayphas included Carmel and the sea shore almost to Chateau Pelerin.

(8.) The Seigneurie of Caymont, a small fief round Tell Keimûn.

(9.) The Prince of Gंalilee occupied the rest of Uंpper Galilee and all the plain of Esdraelon to Petit Gerin (.Jenin). On the south-east the border ran from Le Grand Gerin (Zer'in) by Lecara (Kâra), Hubelet 
(Yebla), and Gebul (Jabbull), having the Valley of Jezreel in the next fief. The borders of the Seigneur of Tiberias in this fief I am not able to define:

(10.) The Seigneurie of Bessan included the Jezreel Valley and Jordan Valley, perhaps as far as Tell er Ridhghah, where the Beisan plain ends.

(11.) The Seigneurie of Casarea included the Sharon plain to the River of Roche Taillie ( $N a h v^{\circ}$ el Fâlik). On the east it ran to the low hills including Hatil ('Attill) and Allar (Ellâr), Caphet (Keffa), Pharaon (Fer'on), and Phardesie (Furdisia).

(12.) The Seigneurie of Arsur, south of the last, and as far south as the Arsur river ( $N a h r$ el 'Auja); extended on the east to include Largieous (Jeiyts).

(13.) The Seigneurie of Naples included the Samaritan hills as far south as Kafarhone (Kefr'Ana) and Val de Curs ('Ain Sinia).

(14.) The Seigneurie of Jaffa and Ascalon belonged to the famous Seigneurs of Ibelin (Yebni). It extended south from the River of Arsur to Gaza, and on the east to Betenable (Boit Nûba), Huldres (Khuldah), Blanche Garde (Tell es Sâfi), Zeite (Zeita), and Agelin ('Ajlân).

(15.) The Seigneurie of Darum, round Deir el Belah.

(16.) The Seigneurie of St, Abrahan included the Hebron hills from Beit Jîbrin eastward. . On the north it seems to have extended to Jamavara (Jemrûrah) and Meimes (Mâmâs).

(17.) The Royal Domain was between St. Abraham and Naples, including the Jerusalem hills and Jericho Vialley. A large proportion of the villages in this region were given by successive kings to the Church of the Holy Sepulchre.

(18.) Oultre Jourdain, the great fief of Renaud of Chatillon, included Gilearl and Moab.

(19.) The Land of Suhete was the Jaulân up to Bânias.

A few notes may be added,

There were three bridges over Jordan in the 12 th century, viz. :-

(1) The bridge of Chastelet $=$ Jisr Benût Y'akub.

(2) The bridge of Sennabra $=$ Jisr es Sidd, just south of the Sea of Galilee, where the ruins of Sinnabris (Sin-en-nâbra) still exist.

(3) The bridge of Judaire = Jisr el Mujamia.

The Jisr ed Dâmieh is alsa probably a Crusading structure, but 1 do not know its Crusading name.

The Lake of Castorie was in the plain near Arsuf. It seems clearly to be the present Bahret Katurieh of the Survey.

M. Rey, in 1883, promised a Crusading map of Palestine. I do not know if this has yet appeared. If so, the fiefs will probably be shown. much as above, since many of the towns noticed in this paper were identified by him.

C. R. CONDER. 